\title{
Thiamine Supplementation is Beneficial as Adjunctive Therapy to ACE Inhibitors to Improve the Course of Nephrogenic Complications of Type II Diabetes Mellitus: Possible Involvement of the Inflammatory Cascade as a Mechanism of this Effect
} \author{
MOHAMED M. KHALIFA, M.D. ${ }^{\mathbf{1}},{ }^{\mathbf{2}}$; AKEF A. KHOWAILED, M.D. ${ }^{\mathbf{1}}$; MINA J. AYAD, M.Sc. ${ }^{\mathbf{3}}$;
HANAN FOUAD, M.D. ${ }^{\mathbf{4}}$ and MAHMOUD R.M. EL-ANSARI, M.D. \\ The Department of Medical Physiology, Kasr Al-Ainy, Faculty of Medicine, Cairo University, Egypt ${ }^{1,}$ \\ Department of Medical Physiology, Faculty of Medicine, King Saud University, Kingdom of Saudia Arabia ${ }^{2}$, \\ Department of Medical Physiology, MUST University, Egypt ${ }^{3}$, Department of Biochemistry, Kasr Al-Ainy, Faculty of Medicine, \\ Cairo University, Egypt ${ }^{4}$ and Department of Microbiology \& Immunology, MUST University, Egypt ${ }^{5}$
}

\begin{abstract}
Background: Diabetic nephropathy is one of the most common complications of type II diabetes mellitus. Different recent researches investigated the therapeutic effects of different medications and therapeutic agents on the progression of diabetic nephropathy.
\end{abstract}

Aim of Study: Compare the reno-protective effects of thiamine in addition to ACE inhibitors in type 2 diabetic kidneys.

Material and Methods: A total of 50 male albino rats were were divided into 5 groups:

Group 1: Control group.

Group 2: Type 2 diabetic rats.

Group 3: Type 2 diabetic nephropathy rats.

Group 4: Lisinopril-treated type 2 diabetic nephropathy rats.

Group 5: Thiamine mononitrate-treated type 2 diabetic nephropathy rats.

Blood samples were collected for the measurements of fasting blood glucose, fasting blood insulin, blood urea, and blood albumin-creatinine ratio. Urine samples were collected for measurement of urinary albumin excretion. Systolic and diastolic blood pressure were measured. Nuclear factor kappaB gene expression was estimated.

Results: Treatment with ACE inhibitors reduced fasting blood glucose, fasting blood insulin, blood urea, urinary albumin excretion, nuclear factor kappa B gene expression, systolic blood pressure and diastolic blood pressure. While treatment with thiamine mononitrate reduced fasting blood glucose, blood urea, urinary albumin excretion and systolic blood pressure.

Conclusion: The use of ACE inhibitors and thiamine in the treatment of kidney disease with type 2 diabetes signifi-

Correspondence to: Dr. Mohamed M. Khalifa, E-Mail: m mmk2050@yahoo.com cantly offered renal protection and improved the diabetic condition and may postpone the onset of renal injury in type 2 diabetic person.

Key Words: Thiamine - Nuclear factor kappa B-Diabetic nephropathy - renoprotection.

\section{Introduction}

DIABETIC nephropathy (DN), also known as Kimmelstiel-Wilson syndrome, or nodular diabetic glomerulosclerosis and intercapillary glomerulonephritis, is a chronic progressive renal disease caused by angiopathy of capillaries in the renal glomeruli. It is characterized by nephrotic syndrome as well as diffuse glomerulosclerosis. It is caused by longstanding diabetes mellitus and is a common indication for dialysis in many countries. It is currently classified as a microvascular complication of diabetes mellitus [1].

Diabetic nephropathy is becoming the most frequent cause of end-stage renal disease (ESRD) in most countries and carries an increased risk for mortality [2].

Hyperglycemia plays a fundamental role in the development of diabetic nephropathy, and multiple interactions have been recently described between the genetic factors and the blood sugar levels for the risk of onset of microalbuminuria in patients with newly developed type 2 diabetes. The combination of positive family history and poor glycemic control dramatically increases the risk for development of diabetic nephropathy [3] 
Furthermore, Diabetic nephropathy is a leading cause of chronic kidney disease in patients starting renal replacement therapy [4].

The reactions forming advanced glycation endproducts (AGEs) by non-enzymatic binding of glucose to other organic compounds as proteins, lipids, and nucleic acids can lead to the alteration of protein structure and function, oxidative stress, and expression of multiple proinflammatory cytokines and growth factors [5]

Oxidative stress and generation of reactive oxygen species (ROS) damage deoxyribonucleic acid (DNA) and protein, or function as signaling amplifiers to activate cellular stress pathways such as protein kinase $\mathrm{C}$ (PKC), mitogen-activated protein kinase (MAPK), and nuclear factor-kappa $\mathrm{B}(\mathrm{NF}-\mathrm{KB})[6]$.

Hyperglycemia induces mitochondrial reactive oxygen species (ROS). Glucose is metabolized through the polyol pathway, leading to a decrease in the amount of reduced nicotinamide adenine dinucleotide phosphate (NADPH) which in turn lowers the availability of glutathione. With less glutathione, ROS will further increase intracellularly [7].

ACE inhibitors (ACEIs) prevent the conversion of angiotensin I to ANG II. They can decrease tissue oxidative stress, and there is a shred of evidence that they lower the formation of AGEs [8]

Dysregulation of RAAS plays a pivotal role in the pathogenesis of diabetic nephropathy [9].

Hyperglycemia is associated with increased production of ANG II in glomerular mesangial cells [10]

Also, renin angiotensin system (RAAS) seems to be involved in podocyte injury through the induction of oxidative stress in diabetic nephropathy [11].

Angiotensin II may enhance the generation of ROS through the activation of NADPH oxidases in podocytes [12]. Leading to microalbuminuria, followed by macroalbuminuria and finally chronic renal failure [13].

Thiamine acts as a coenzyme for the enzymes transketolase (TK), pyruvate dehydrogenase (PDH) and alpha-ketoglutarate dehydrogenase enzyme complexes, enzymes which play a fundamental role in intracellular glucose metabolism. A thiamine/ TK activity deficiency has been described in diabetic patients [14]

Recent evidence suggests that insulin resistance forces the pancreas to increase its insulin secretion, which stresses the $\beta$ cells, resulting in the exhaustion of $\beta$-cells. The high blood glucose and saturated fatty acids levels create an inflammatory medium, resulting in activation of the non-specific immune system, resulting in the activation of the NF- $\kappa B$, and release of inflammatory mediators [15]

$\mathrm{NF}-\kappa \mathrm{B}$ is the most critical transcription factor involved in the pathophysiology of diabetic nephropathy. It helps to control the expression of numerous genes activated during inflammation [16]

Hyperglycemia itself can activate NF- $\kappa B$ in endothelial cells, vascular smooth muscle cells and proximal tubule cell [17]

Angiotensin II has been added to the list of essential molecules that activate NF- $\kappa B$. Angiotensin activates NF- $\kappa \mathrm{B}$ in the kidney via Angiotensin II receptor type 1 (AT1R) and Angiotensin II receptor type 2 (AT2R), and that this peptide participates in the mononuclear cell recruitment in experimental nephritis through NF- $\kappa B$ [18]

Moreover, as proteinuria can also elicit the synthesis of ANGII in renal cortex and NF- $\kappa \mathrm{B}$ activation, this pathway has been recently proposed as a mechanism by which persistent proteinuria may contribute in the progression of pathological renal changes [19].

In streptozotocin-induced diabetes, NF- $\kappa B$ activation in renal cortical tissue has been reported [20], and in vitro studies have indicated that AGEs induce oxidative stress and activate NF- $\kappa B$ in mesangial cells [21].

Other studies in patients with type 1 and type 2 diabetes have reported that insufficient glycemic control increases NF-kB binding activity in peripheral blood mononuclear cells [22]

Thiamine, is a vitamin of the B complex. The best-characterized form is thiamine diphosphate (ThDP), also sometimes called thiamine pyrophosphate (TPP), a coenzyme in the catabolism of sugars and amino acids [23]

Thiamine has a fundamental role in the energyyielding metabolic reactions, especially the metabolism of carbohydrates. Thiamine diphosphate is 
the coenzyme for three multienzyme complexes that catalyze oxidative decarboxylation reactions: Pyruvate dehydrogenase (PDH) in carbohydrate metabolism; a-ketoglutarate dehydrogenase in the citric acid cycle; and the branched-chain a-ketoacid dehydrogenase (BCKDH) involved in the metabolism of leucine, isoleucine, and valine [24]

In humans, acute thiamine deficiency can be manifested by diabetic ketoacidosis (DKA), lactic acidosis and hyperglycemia [25]

Pentose phosphate pathway (PPP) represents an alternative route for glucose oxidation fulfilling three crucial functions: (1) Production of reducing equivalent NADPH necessary for reduction of oxidized glutathione thus supporting intracellular antioxidant defenses; (2) Output of ribose-5phosphate required for the synthesis of nucleotides; and (3) Metabolic use of pentoses obtained from the diet. Thiamine may have significant effects on the glucose metabolism through the regulation of Pentose Phosphate pathway. Indeed, TK activation by benfotiamine in endothelial cells blocked several pathways which are responsible for the damage caused by hyperglycemia and prevented development and progression of diabetic complications in animal models [26]

However, little is currently known about the exact mechanisms by which diabetes affects thiamine metabolism [27]

Thiamine deficiency diminishes the mRNA levels of Tk and PDH [28]. Pyruvate dehydrogenase activity is also reduced in diabetic patients [29]

\section{The aim of the work}

The objective of this study is to:

1-Test and compare the possible protective effects of thiamine when added to ACEIs in the course of diabetic nephropathy in type II diabetic rats.

2- Test the role of the inflammatory pathway (cascade) in the promotion \& progression of nephrogenic complications in type II diabetic rats.

\section{Material and Methods}

This study was conducted in El-Kasr El-Eini physiology department's laboratory.

It lasted 3 months from February 2016 till May 2016. All chemical agents and medications were purchased from the Egyptian international Pharmaceuticals and chemicals company, 10 th of Ramadan City, Industrial Zone B (E.I.P.I.C.O).

\section{Experimental animals:}

A total of 50 male albino rats were used in this study weighing 150-200 grams.

The animals were housed in wire mesh cages at room temperature, with a regular light-dark cycle. They were fed the commercial rat chow diet and had free access to water.

\section{Ethical consideration:}

All experimental protocols described in the present study were approved by the Ethics Review Committee for Animal Experimentation of Faculty of medicine, Cairo University.

The animals were divided into the following groups: Group 1: Control group $(\mathrm{n}=10)$ :

- Consists of 10 normal rats not subjected to any drug.

Group 2: Type 2 diabetic rats $(\mathrm{n}=10)$ :

- They were sacrificed after type II diabetes was confirmed

Group 3: Diabetic nephropathy (DN) rats $(\mathrm{n}=10)$ :

- Microalbuminuria was established in type II diabetic rats

Group 4: Lisinopril protected Diabetic nephropathy $(\mathrm{DN})$ rats $(\mathrm{n}=10)$ :

- Diabetic nephropathy rats were treated with oral lisinopril $10 \mathrm{mg} / \mathrm{kg} /$ day for one month [30]

Group 5: Thiamine protected Diabetic nephropathy $(\mathrm{DN})$ rats $(\mathrm{n}=10)$ :

- Diabetic nephropathy rats were treated with high dose oral thiamine mononitrate $70 \mathrm{mg}$ $/ \mathrm{kg} /$ day for one month [31]

\section{Induction of Type 2 diabetes:}

Beginning on day 0 , rats were fed either standard rodent chow (group 1) or high-fat diet (Other groups). On day 14, rats on the high-fat diet were injected with a single low dose of streptozotocin $(\mathrm{HFD}+\mathrm{STZ})(\mathrm{STZ}, 30 \mathrm{mg} / \mathrm{kg}$ i.p., in $0.01 \mathrm{M}$ citrate buffer $\mathrm{pH} 4.3$ ) to induce type 2 diabetes [32]

Consumption of a high-fat diet eventually leads to the development of insulin resistance and is considered to be a major predisposing factor for type 2 diabetes [33]. Subsequent to STZ treatment, rats had free access to food and water and were continued on their planned diets for the duration of the study. 
STZ causes hyperglycemia by specifically inducing DNA strand breaks in pancreatic islet-cells and stimulates nuclear poly (ADP-ribose) synthetase, thus depleting intracellular Nicotinamide adenine dinucleotide (NAD+) and Nicotinamide adenine dinucleotide phosphate (NADP+) levels. Reduction of NAD+ and NADP+ inhibits proinsulin synthesis, leading to a diabetic state [34]

Characterization of Type 2 diabetes and diabetic nephropathy models:

On day 20, in the HFD + STZ groups, type 2 diabetes was confirmed by measuring fasting plasma glucose and insulin levels. Blood was sampled from the retro-orbital plexus under diethyl ether anesthesia was used to measure plasma glucose and insulin concentrations. Rats that had high blood glucose level were considered as diabetic and were used for further study. 10 rats were sacrificed and were considered as group 2 .

The onset of diabetic nephropathy in the remaining rats began subtly after one month of diabetes [35]. It was confirmed by the presence of microalbuminuria. 10 rats were considered diabetic nephropathy rats and were categorized as group 3 . Group 4 included 10 rats that were treated with oral lisinopril 10mg/kg/day for 1 month [30]. Group 5 included 10 rats that were treated with high dose oral thiamine mononitrate $70 \mathrm{mg} / \mathrm{kg} / \mathrm{day}$ for 1 month [31].

Blood and urine samples from groups 1,3,4 and 5 were taken at the end of the study protocol.

\section{Methods:}

1- Measurement of fasting plasma Glucose level according to (www. amsalliance.com):

\section{Intended use:}

AMS glucose kit utilizes the enzymatic colorimetric technique for the quantitative determination of glucose in serum, plasma, and urine using the AMS SAT 450 Chemistry System.

\section{2 - Measurement of the fasting plasma insulin level (according to de la Rica and Stevens, 2012) [36]:}

In the previously frozen and thawed serum samples, insulin concentrations were measured by the method of enzymatic immunoassay using Rat Insulin ELISA kits.

\section{Renal function tests:}

3- Measurement of blood urea according to (www. amsalliance.com):

\section{Intended use:}

AMS urea UV kit utilizes the enzymatic method for the quantitative determination of urea in serum, plasma, and urine using the AMS SAT 450 Chemistry System.

\section{4 - Measurement of blood creatinine according to (www. amsalliance.com):}

\section{Intended use:}

AMS creatinine enzymatic kit utilizes the enzymatic calorimetric method for the quantitative determination of creatinine in serum, plasma, and urine using the AMS sat 450 chemistry system.

\section{5- Measurement of albumin in blood and urine according to (www. amsalliance.com):}

Intended use:

AMS albumin kit utilizes the colorimetric method (BCG) for the quantitative determination albumin in serum and urine using AMS SAT $450 \mathrm{Chem}-$ istry System.

\section{6- Measurement of the arterial blood pressure:}

Blood pressure was measured in the conscious experimental animals immediately before obtainingthe blood samples. The rats were trained to the apparatus several times before the measurement. Blood pressurewas measured in the tail region using an electronic electro sphygmomanometer device after the animal was pre-warmed for 15 $\mathrm{min}$ in order to increase theambient temperature to $37^{\circ} \mathrm{C}$ and to maintain an adequate circulation in the animal's tail to ensure a reliable measurement of the arterial blood pressure.

The Harvard Rat Tail electronic blood Pressure Monitor system is an electronic version of the traditional sphygmomanometer measurement cuff method, used to determine blood pressure from the animal's tail indirectly.

At least three consecutive readings were taken each time for obtaining the average and as a proof of accurate systolic blood pressure measurements.

Both cuff pressure and pulse are recorded simultaneously. While the cuff pressure is above the systolic pressure, little or no vibration was observed on the pulse channel of the chart recorder. Systolic pressure is obtained as the pressure at which the pulse first appears. While the diastolic blood pressure is estimated by calculation using a software algorithm [37] 
7- $\Lambda$ тг-к(3 gene expression semiquantitation (according to Hinfa et al., 2009) pn:

Reverse transcriptase-polymerase chain reaction (KT-PCK):

1- Total RNA was extracted from whole blood using the RNeasy purification reagent (Cat No. 74134, Qiagen, Valencia, CA, USA).

2- Reverse transcription and PCR was conducted using the One Step RT-PCR Kit (Qiagen, USA, catalog number 210212).

\section{PCR Detection of beta-Actin:}

The presence of RNA in all tissues was assessed by analysis of the "house-keeping" gene (3-actin. [3-actin primers (forward 5'-TGTTGTCCCT

GTATGCCTCT-3' , reverse 5' -TAATGTCAC GCACGATT'TCC-3') were designed from GenHank (accession no. 300691) and amplified a product of 20бьp.

\section{Gel Electrophoresis:}

PCK products of (NE-0 and beta actin) genes were electrophorized on $2 \%$ agarose gel stained with ethidium bromide and visualized by ultraviolet transilluminator. Semiquantitation of PCR product was conducted using gel documentation system (BioDocAnalyze System and software, Biometra, Germany, Gëttingen).

\section{Statistical analysis:}

Data were statistically described and compared regarding mean \pm standard deviation $( \pm S D)$ using the two-sided Student t-test for independent samples. All statistical calculations and analysis were done using the computer program SPSS (Statistical
Package for the Social Science; MM Corp, Armonk, NY, USA) release 22 for Microsoft Windows.

The $\mathrm{p}$-value or calculated probability was determined. p-values less than 0.05 were considered statistically significant. While p-values less than 0.01 were considered highly significant. p-values of more than 0.05 were considered insignificant.

\section{Results}

\section{Comparative data of the five studied groups:}

Table (1) shows that there is a highly statistically significant difference between group 1 and group 3 as regard blood urea, urinary albumin excretion, blood albumin creatinine ratio, fasting blood glu-


SBP and DBP $(p<0.01)$. Group 3 had higher blood urea, urinary/albumin excretion, blood albumin creatinine ratio, fasting blood glucose, fasting blood insulin, NE-кp gene expression, SBP and DBP than group 1.

The table also shows that there is a highly statistically significant difference between group 2 and group 3 regarding blood urea, urinary albumin excretion, blood albumin creatinine ratio, fasting blood glucose and SBP $(p<0.01)$. While there is a statistically significant difference between group 2 and group 3 as regard fasting blood insulin and DBP $(p<0.05)$. Group 3hadhigher blood urea, urinary albumin excretion, fasting blood glucose, fasting blood insulin, SBP and DBP, and had a lower blood albumin/creatinine ratio, than group 2. Group 3 had a statistically insignificant higher ME-kf3 gene expression than group 2.

Table (1): Effect of diabetic nephropathy (DN) on all studied parameters.

\begin{tabular}{|c|c|c|c|c|c|c|c|}
\hline & \multicolumn{2}{|c|}{ Group 1} & \multicolumn{2}{|c|}{ Group 2} & \multicolumn{2}{|c|}{ Group 3} & \multirow{2}{*}{$\mathrm{p}$-value } \\
\hline & Меап & t SD & Mean & t SD & Меап & t SD & \\
\hline Blood urea $(\mathrm{mg} / \mathrm{d} 1)$ & 26.41 & 1.654 & 26.59 & 1 & 29.33 & 1.947 & $\begin{array}{l}0.002 * \\
0.001\end{array}$ \\
\hline Urinary albumin excretion (grn/d1) & 0.028 & 0.012 & 0.03 & 0.006 & 0.437 & 0.093 & $\begin{array}{l}0.0 \mathrm{co}^{*} \\
0.000\end{array}$ \\
\hline Blood albumin creatinine ratio (iig/mg) & 140.7 & 25.082 & ioi .775 & 4.605 & 39.629 & 1.747 & $\begin{array}{c}0.000^{*} \\
0.000^{\bullet}\end{array}$ \\
\hline Blood glucose (mg/di) & 89.6 & 20.239 & 212.7 & 7.212 & 229.6 & 9.442 & $\begin{array}{l}0.000^{*} \\
0.000-\end{array}$ \\
\hline Blood insulin $04 \mathrm{~g} / 1$ ) & 0.461 & $(1056$ & 4.19 & 0.87 & 5.14 & 0.677 & $\begin{array}{l}0.000^{*} \\
0.014\end{array}$ \\
\hline $\mathrm{N}_{\Gamma-\mathrm{KB}}$ gene expression & 0.571 & 0.034 & 0.97 & 0.116 & 1.09 & 0.263 & $\begin{array}{l}0.000^{*} \\
0.203^{\bullet}\end{array}$ \\
\hline $\mathrm{SBP}(\mathrm{mmHg})$ & 112.3 & 9.25 & ізб & 5.164 & 149 & 8.433 & $\begin{array}{l}\text { O.O0O* } \\
\text { OOH. }\end{array}$ \\
\hline DBP (mmHg) & 76.8 & Ю.83 & 92 & 2.582 & 95.5 & 4.378 & $\begin{array}{l}0.000 * \\
0.043\end{array}$ \\
\hline
\end{tabular}


Table (2) shows that there is a highly statistically significant difference between group 1 and group 4 as regard urinary albumin excretion, blood albumin creatinine ratio, fasting blood glucose, fasting blood insulin $(p<0.01)$. While there is a statistically significant difference between group 1 and group 4 regardingNF-кB gene expression $(p<0.05)$. Group 4 had a higher urinary albumin excretion, fasting blood glucose, fasting blood insulin, and NF- $\mathrm{KB}$ gene expression, and had a lower albumin creatinine ratio, than group 1 . Group 4hadstatistically insignificant higher blood urea, SBP, and DBP than group 1.

The table also shows that there is a highly statistically significant difference between group 2 and group 4 as regard urinary albumin excretion, blood albumin creatinine ratio, fasting blood glucose, NF- $к \mathrm{~B}$ gene expression and SPB $(p<0.01)$.
While there is a statistically significant difference between group 2 and group 4 as regard DBP $(p<0.05)$. Group 4 had a higher urinary albumin excretion, and had a lower blood albumin creatinine ratio, fasting blood glucose, NF- $\mathrm{\kappa B}$ gene expression, SPB and DBP, than group 2. Group 4 had a statistically insignificant lower blood urea, fasting blood insulin than group 2 .

The table also shows that there is a highly statistically significant difference between group 3 and group 4 as regard blood urea, urinary albumin excretion, blood albumin creatinine ratio, fasting blood glucose, fasting blood insulin, NF- $\mathrm{\kappa B}$ gene expression, SBP and DBP $(p<0.01)$. Group 4 had a higher blood albumin creatinine ratio, and had a lower blood urea, urinary albumin excretion, fasting blood glucose, fasting blood insulin, NF$\kappa \mathrm{B}$ gene expression, SBP and DBP, than group 3.

Table (2): Effect of lisinopril treatment on diabetic nephropathy (DN) rats for one month on all studied parameters.

\begin{tabular}{|c|c|c|c|c|c|c|c|c|c|}
\hline & \multicolumn{2}{|c|}{ Group 1} & \multicolumn{2}{|c|}{ Group 2} & \multicolumn{2}{|c|}{ Group 3} & \multicolumn{2}{|c|}{ Group 4} & \multirow{2}{*}{$p$-value } \\
\hline & Mean & $\pm \mathrm{SD}$ & Mean & $\pm \mathrm{SD}$ & Mean & $\pm \mathrm{SD}$ & Mean & $\pm \mathrm{SD}$ & \\
\hline Blood urea (mg/dl) & 26.41 & 1.654 & 26.59 & 1 & 29.33 & 1.947 & 26.53 & 1.486 & $\begin{array}{l}0.866 \\
0.917 \\
0.002\end{array}$ \\
\hline $\begin{array}{l}\text { Urinary albumin excre- } \\
\text { tion }(\mathrm{gm} / \mathrm{dl})\end{array}$ & 0.028 & 0.012 & 0.03 & 0.006 & 0.437 & 0.093 & 0.091 & 0.012 & $\begin{array}{l}0.000^{*} \\
0.000 \\
0.000 \bullet\end{array}$ \\
\hline $\begin{array}{l}\text { Blood albumin creati- } \\
\text { nine ratio }(\propto \mathrm{g} / \mathrm{mg})\end{array}$ & 140.7 & 25.082 & 101.775 & 4.605 & 39.629 & 1.747 & 70.171 & 4.863 & $\begin{array}{l}0.000^{*} \\
0.000 \\
0.000 \bullet\end{array}$ \\
\hline Blood glucose $(\mathrm{mg} / \mathrm{dl})$ & 89.6 & 20.239 & 212.7 & 7.212 & 229.6 & 9.442 & 197.8 & 10.993 & $\begin{array}{l}0.000^{*} \\
0.002 \\
0.000 \bullet\end{array}$ \\
\hline Blood insulin $(\propto \mathrm{g} / \mathrm{l})$ & 0.461 & 0.056 & 4.19 & 0.87 & 5.14 & 0.677 & 3.68 & 0.634 & $\begin{array}{l}0.000^{*} \\
0.151 \\
0.000\end{array}$ \\
\hline NF-кB gene expression & 0.571 & 0.034 & 0.97 & 0.116 & 1.09 & 0.263 & 0.669 & 0.102 & $\begin{array}{l}0.010^{*} \\
0.000 \\
0.000 \bullet\end{array}$ \\
\hline $\mathrm{SBP}(\mathrm{mmHg})$ & 112.3 & 9.25 & 136 & 5.164 & 149 & 8.433 & 113.4 & 8.316 & $\begin{array}{l}0.783 \\
0.000 \\
0.000 \bullet\end{array}$ \\
\hline $\mathrm{DBP}(\mathrm{mmHg})$ & 76.8 & 10.83 & 92 & 2.582 & 95.5 & 4.378 & 82.5 & 10.906 & $\begin{array}{l}0.256 \\
0.015 \\
0.003 \text { • }\end{array}$ \\
\hline
\end{tabular}

* $p$-values significant change comparing group 4 to group 1

$p$-values significant change comparing group 4 to group 2.

- $p$-values significant change comparing group 4 to group 3. 
Table (3) shows that there is a highly statistically significant difference between group 1 and group 5 as regard urinary albumin excretion, blood albumin creatinine ratio, fasting blood glucose, fasting blood insulin, NF- $\kappa \mathrm{B}$ gene expression, SBP and DBP $(p<0.01)$. Group 5 had a higher urinary albumin excretion, fasting blood glucose, fasting blood insulin, NF- $\mathrm{KB}$ gene expression, SBP and DBP, and had a lower blood albumin creatinine ratio, than group 1 . Group 5 had a statistically insignificant higher blood urea than group 1 .

The table also shows that there is a highly statistically significant difference between group 2 and group 5 as regard urinary albumin excretion and blood albumin creatinine ratio $(p<0.01)$. While there is a statistically significant difference between group 2 and group 5 as regard fasting blood insulin $(p<0.05)$. Group 5 had a higher urinary albumin excretion and fasting blood insulin than group 2 . Group 5 had a statistically insignificant higher blood urea, NF- $\kappa \mathrm{B}$ gene expression and DBP, and insignificant lower fasting blood glucose, than group 2.

The table also shows that there is a highly statistically significant difference between group 3 and group 5 as regard blood urea, urinary albumin excretion, blood albumin creatinine ratio and fasting blood glucose $(p<0.01)$. While there is a statistically significant difference between group 3 and group 5 as regard SBP $(p<0.05)$. Group 5 had a higher blood albumin creatinine ratio, and had a lower blood urea, urinary albumin excretion, fasting blood glucose and SBP, than group 3 .

Table (3): Effect of thiamine mononitrate treatment on DN rats for one month on all studied parameters.

\begin{tabular}{|c|c|c|c|c|c|c|c|c|c|c|c|}
\hline & \multicolumn{2}{|c|}{ Group 1} & \multicolumn{2}{|c|}{ Group 2} & \multicolumn{2}{|c|}{ Group 3} & \multicolumn{2}{|c|}{ Group 4} & \multicolumn{2}{|c|}{ Group 5} & \multirow{2}{*}{$\begin{array}{c}p- \\
\text { value }\end{array}$} \\
\hline & Mean & $\pm \mathrm{SD}$ & Mean & $\pm \mathrm{SD}$ & Mean & $\pm \mathrm{SD}$ & Mean & $\pm \mathrm{SD}$ & Mean & $\pm \mathrm{SD}$ & \\
\hline Blood urea (mg/dl) & 26.41 & 1.654 & 26.59 & 1 & 29.33 & 1.947 & 26.53 & 1.486 & 26.99 & 1.388 & $\begin{array}{l}0.407 \\
0.469 \\
0.006 \bullet \\
0.484\end{array}$ \\
\hline $\begin{array}{l}\text { Urinary albumin } \\
\text { excretion }(\mathrm{gm} / \mathrm{dl})\end{array}$ & 0.028 & 0.012 & 0.03 & 0.006 & 0.437 & 0.093 & 0.091 & 0.012 & 0.125 & 0.013 & $\begin{array}{l}0.000^{*} \\
0.000 \\
0.000 \bullet \\
0.000 \mathrm{~s}\end{array}$ \\
\hline $\begin{array}{l}\text { Blood albumin } \\
\text { creatinine ratio } \\
(\text { g/ng) }\end{array}$ & 140.7 & 25.082 & 101.775 & 4.605 & 39.629 & 1.747 & 70.171 & 4.863 & 64.05 & 4.885 & $\begin{array}{l}0.000^{*} \\
0.000 \\
0.000 \bullet \\
0.012 \mathrm{~s}\end{array}$ \\
\hline Blood glucose (mg/dl) & 89.6 & 20.239 & 212.7 & 7.212 & 229.6 & 9.442 & 197.8 & 10.993 & 207.4 & 5.719 & $\begin{array}{l}0.000^{*} \\
0.085 \\
0.000 \bullet \\
0.025 \mathrm{~s}\end{array}$ \\
\hline Blood insulin ( $\mathrm{g} / \mathrm{l}$ & 0.461 & 0.056 & 4.19 & 0.87 & 5.14 & 0.677 & 3.68 & 0.634 & 4.94 & 0.566 & $\begin{array}{l}0.000 * \\
0.035 \\
0.483 \\
0.000 \mathrm{~s}\end{array}$ \\
\hline $\begin{array}{r}\text { NF- } \kappa \mathrm{B} \text { gene } \\
\text { expression }\end{array}$ & 0.571 & 0.034 & 0.97 & 0.116 & 1.09 & 0.263 & 0.669 & 0.102 & 0.992 & 0.032 & $\begin{array}{l}0.000^{*} \\
0.570 \\
0.257 \\
0.000 \mathrm{~s}\end{array}$ \\
\hline $\mathrm{SBP}(\mathrm{mmHg})$ & 112.3 & 9.25 & 136 & 5.164 & 149 & 8.433 & 113.4 & 8.316 & 136 & 11.832 & $\begin{array}{l}0.000^{*} \\
1.000 \\
0.011 \bullet \\
0.000 \mathrm{~s}\end{array}$ \\
\hline $\mathrm{DBP}(\mathrm{mmHg})$ & 76.8 & 10.83 & 92 & 2.582 & 95.5 & 4.378 & 82.5 & 10.906 & 93.5 & 3.375 & $\begin{array}{l}0.000 * \\
0.279 \\
0.268 \\
0.007 \mathrm{~s}\end{array}$ \\
\hline
\end{tabular}

${ }^{*} p$-values significant change comparing group 5 to group. $\quad p$-values significant change comparing group 5 to group 2.

- $p$-values significant change comparing group 5 to group 3. s $p$-values significant change comparing group 5 to group 4. 
Group 5 had a statistically insignificant lower fasting blood insulin, NF- $\kappa \mathrm{B}$ gene expression and DBP than group 3.

The table also shows that there is a highly statistically significant difference between group 4 and group 5 as regard urinary albumin excretion ratio, fasting blood insulin, NF- $\kappa$ Bgene expression, SBP and DBP $(p<0.01)$. While there is a statistically

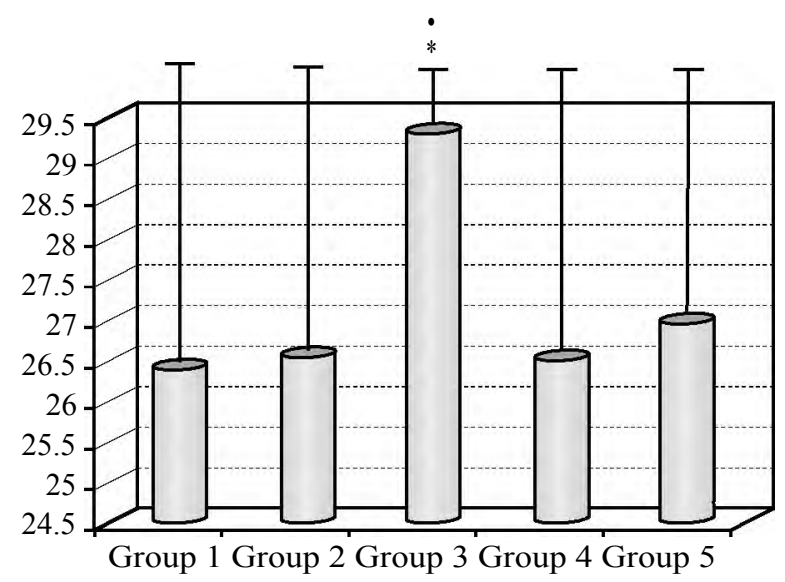

Fig. (1): Mean blood urea among the studied groups.

Values are represented as mean $\pm \mathrm{SD}$.

* : Statistically significant change comparing groups 5,4,3 and 2 to group $1(p<0.05)$

- : Statistically significant change comparing groups 5,4 and 3 to group $2(p<0.05)$.

Statistically significant change comparing groups 5 and 4 to group $3(p<0.05)$.

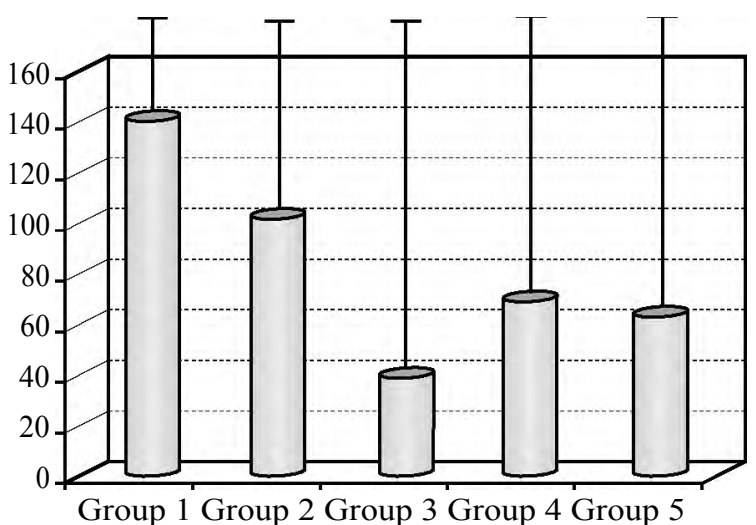

Fig. (3): Mean blood albumin creatinine ratio among the studied groups.

Values are represented as mean $\pm \mathrm{SD}$.

: Statistically significant change comparing groups $5,4,3$ and 2 to group $1(p<0.05)$

- : Statistically significant change comparing groups 5,4 and 3 to group $2(p<0.05)$.

Statistically significant change comparing groups 5 and 4 to group $3(p<0.05)$.

$\mathrm{s}$ : Statistically significant change comparing group 5 to group 4 $\left(p^{<0.05) \text {. }}\right.$ significant difference between group 4 and group 5 as regard blood albumin creatinine ratio and fasting blood glucose $(p<0.05)$. Group 5 had a higher urinary albumin excretion, fasting blood glucose, fasting blood insulin, NF- $\kappa B$ gene expression, SBP and DBP, and had a lower blood albumin creatinine ratio, than group 4 . Group 5 had a statistically insignificant higher blood urea than group 4 .

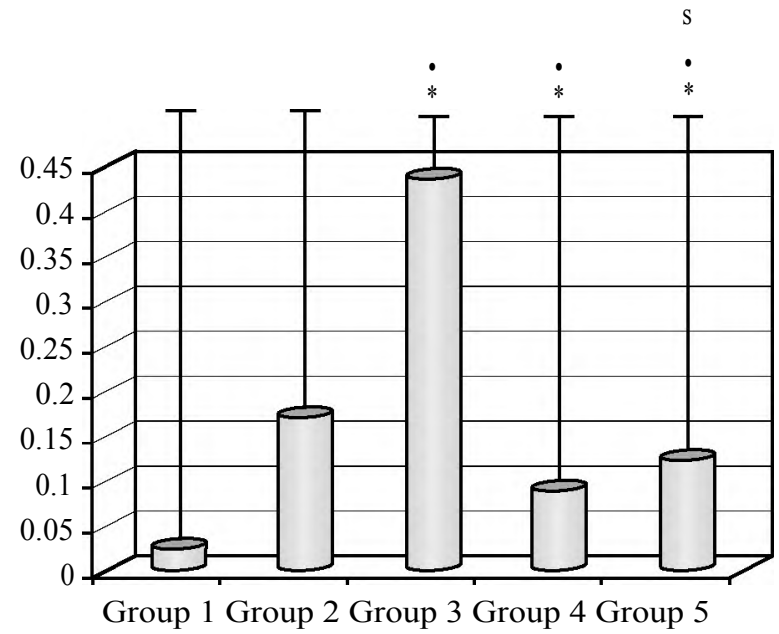

Fig. (2): Mean urinary albumin excretion among the studied groups.

Values are represented as mean $\pm \mathrm{SD}$.

* : Statistically significant change comparing groups 5,4,3 and 2 to group $1(p<0.05)$

- : Statistically significant change comparing groups 5,4 and 3 to group $2(p<0.05)$.

Statistically significant change comparing groups 5 and 4 to group $3(p<0.05)$.

$\mathrm{s}$ : Statistically significant change comparing group 5 to group 4 $\left(p^{<0.05) \text {. }}\right.$

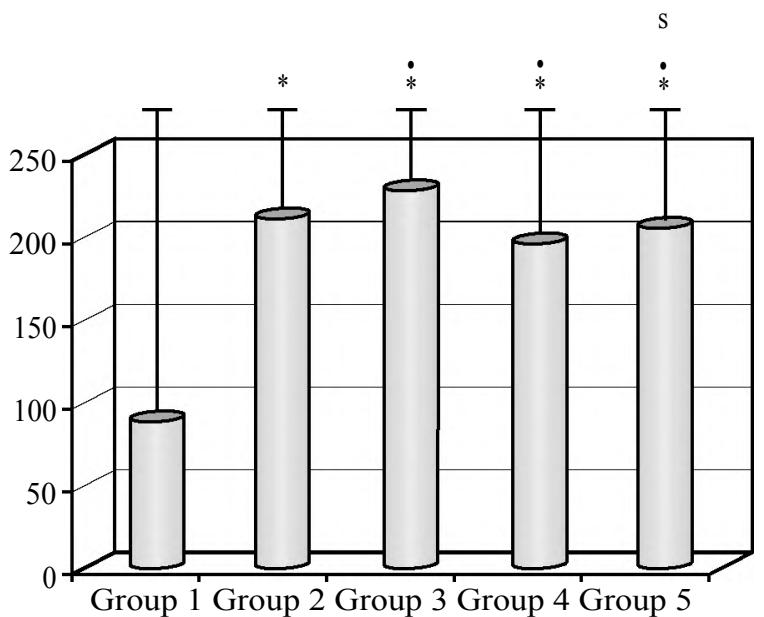

Fig. (4): Mean blood glucose among the studied groups.

Values are represented as mean \pm SD

* : Statistically significant change comparing groups 5,4,3 and 2 to group $1(p<0.05)$

- : Statistically significant change comparing groups 5,4 and 3 to group $2(p<0.05)$

Statistically significant change comparing groups 5 and 4 to group $3(p<0.05)$

$\mathrm{s}$ : Statistically significant change comparing group 5 to group 4 $(p<0.05)$ 


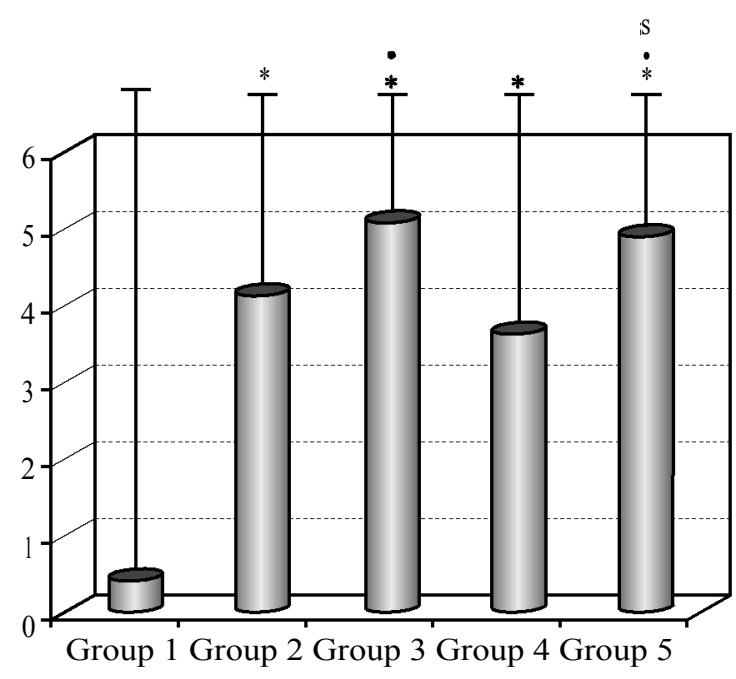

Fig. (5): Mean blood insulin among the studied groups.

Values are represented as mean \pm SD

* : Statistically significant change comparing groups 5,4,3 and 2 to group $1(p<0.05)$.

- : Statistically significant change comparing groups 5,4 and 3 to group $2(p<0.05)$.

: Statistically significant change comparing groups 5 and 4 to group $3(p<0.05)$.

$\mathrm{s}$ : Statistically significant change comparing group 5 to group 4 $(p<0.05)$.

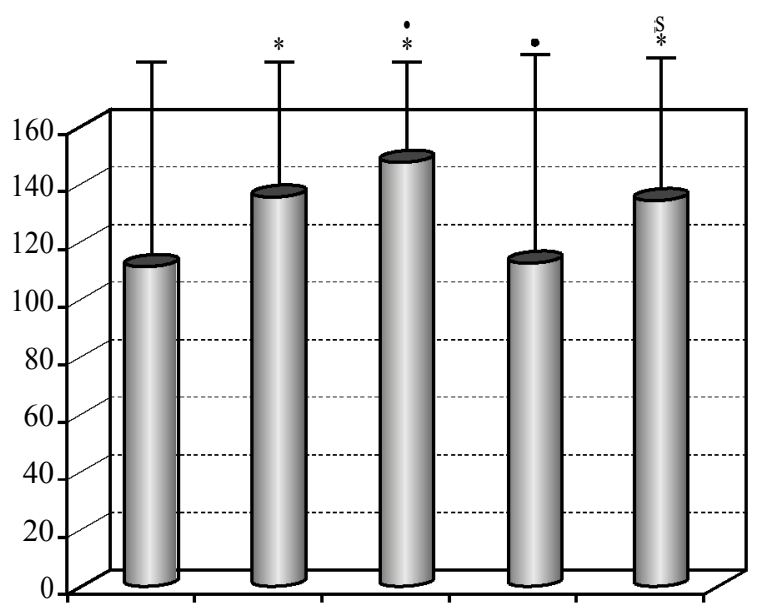

Group 1 Group 2 Group 3 Group 4 Group 5

Fig. (7): Mean systolic blood pressure among the studied groups.

Values are represented as mean $\pm \mathrm{SD}$

* : Statistically significant change comparing groups 5,4,3 and 2 to group $1(p<0.05)$

- : Statistically significant change comparing groups 5,4 and 3 to group $2(p<0.05)$

: Statistically significant change comparing groups 5 and 4 to group $3(\underline{p}<0.05)$.

$\mathrm{s}$ : Statistically significant change comparing group 5 to group 4 $(p<0.05)$.

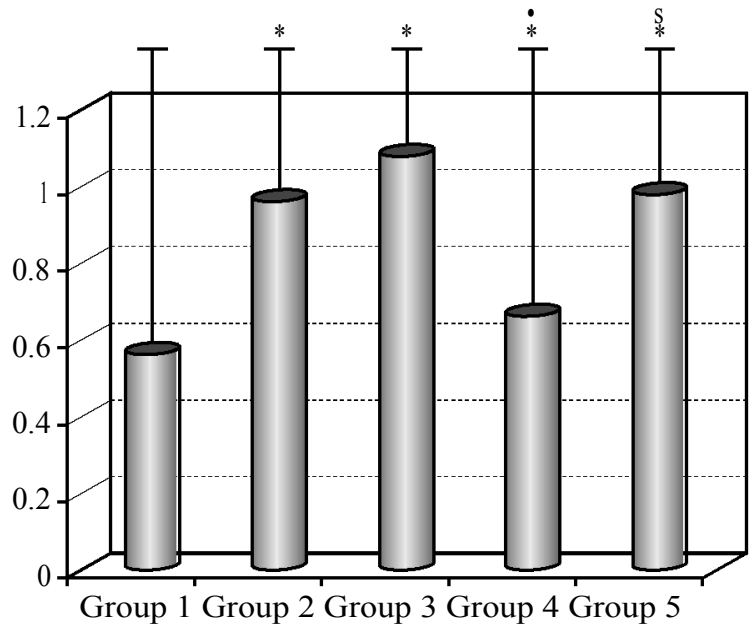

Fig. (6): Mean NF- $\mathrm{KB}$ gene expression among the studied groups

Values are represented as mean $\pm \mathrm{SD}$

* : Statistically significant change comparing groups 5,4,3 and 2 to group $1(p<0.05)$.

- : Statistically significant change comparing groups 5,4 and 3 to group $2(p<0.05)$.

: Statistically significant change comparing groups 5 and 4 to group $3(p<0.05)$.

$\mathrm{s}$ : Statistically significant change comparing group 5 to group 4 $(p<0.05)$.

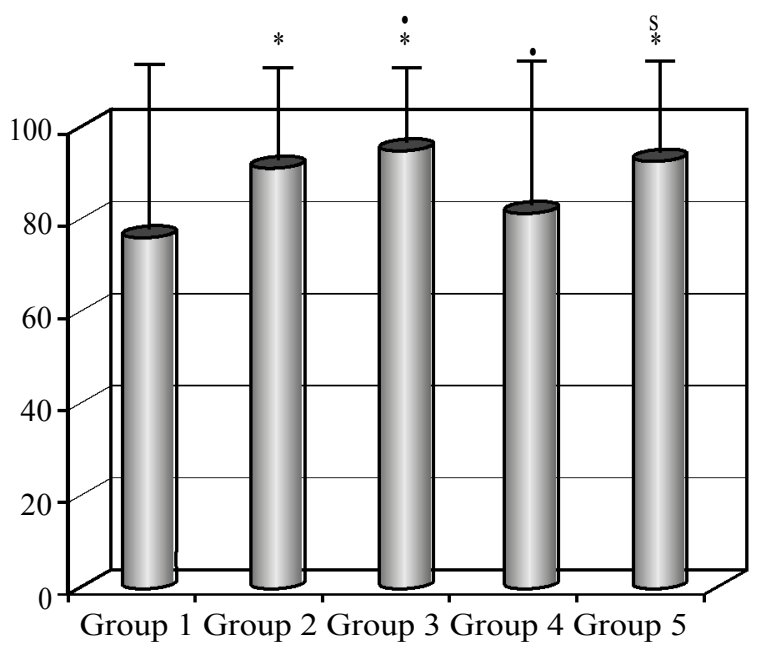

Fig. (8): Mean diastolic blood pressure among the studied groups.

Values are represented as mean $\pm \mathrm{SD}$

* : Statistically significant change comparing groups 5,4,3 and 2 to group $1(p<0.05)$.

- : Statistically significant change comparing groups 5,4 and 3 to group $2(p<0.05)$.

: Statistically significant change comparing groups 5 and 4 to group $3(p<0.05)$.

$\mathrm{s}:$ Statistically significant change comparing group 5 to group 4 $(p<0.05)$. 


\section{Discussion}

Induction of type II diabetes produced a significant increase in SBP and DBP relative to the control group. Type II diabetic rats developed diabetic nephropathy (group 3). DN rats showed a significant increase in SBP and DBP relative to both control and diabetic groups (Figs. 7,8).

This result comes in agreement with Zhou et al., [39] who stated that insulin resistance plays an important role as a risk factor in the pathogenesis of hypertension in patients with type 2 diabetes.

Insulin resistance and hyperinsulinemia are implicated in the development of hypertension through abnormalities in insulin signaling, associated cardiovascular and metabolic pathological changes as well as vascular stiffness, enhanced sympathetic and Renin angiotensin aldosterone system (RAAS) activity with subsequent sodium retention and volume expansion, progressive renal disease and endothelial dysfunction [40] .

It is now evident that another major causes of hypertension in diabetic nephropathy include volume expansion due to increased renal sodium reabsorption and peripheral vasoconstriction caused by the dysregulation of the Renin-Angiotensin system (RAAS) [41].

Type II diabetic rats in our study also showed an insignificant increase in blood urea (Fig. 1) and urinary albumin excretion (UAE) (Fig. 2), while there was a significant decrease in albumin/creatinine ratio (Fig. 3), maybe as a result of the elevated blood level of creatinine due to renal insult.

Type II diabetic nephropathy rats also showed a significant increase in fasting blood glucose (Fig. 4), fasting blood insulin (Fig. 5), relative to both control and diabetic groups.

It has been demonstrated that the renin angiotensin aldosterone system (RAAS), regulates skeletal muscle insulin sensitivity through different mechanisms. The overactivation of the Renin ANG II axis has been associated with the development of insulin resistance [42].

In type II diabetic nephropathy rats, compared to the control and the diabetic group, blood urea and UAE were significantly increased (Fig. 1,2), and blood albumin/creatinine ratio was significantly reduced (Fig. 3).

As diabetic nephropathy starts to develop, the kidney's filtration function usually remains normal during this period. As the disease progresses further and the amount of albumin in the urine increases, the kidney's filtration function usually begins to drop, resulting in the body's retention of various wastes, such as urea and creatinine [43].

Satchell and Tooke [44], mentioned that the glomerular endothelium is the initial site damaged leading to the development of microalbuminuria in diabetes. The mechanism of this damage is disruption of the endothelial glycocalyx which is a protein-rich surface layer on the endothelium, through actions of mediators dysregulated by the diabetic milieu. Structural changes in the glomerulus, including podocyte damage and loss, eventually lead to progression of microalbuminuria to overt nephropathy.

Moreover, there is a positive link between high blood pressure and microalbuminuria. High blood pressure may cause microalbuminuria by increasing glomerular filtration pressure and subsequent renal damage. There may also be common genetic factors that predispose to both high blood pressure and microalbuminuria [45].

In our study, induction of type II diabetes also leads to a significant increase in NF- $\kappa \mathrm{B}$ gene expression. Type II diabetic nephropathy rats also showed a significant increase in NF- $\kappa \mathrm{B}$ gene expression compared to the control group (Fig. 7), but the change was insignificant relative to the diabetic group, indicating continuous renal insult.

Type II diabetes is associated with low-grade systemic inflammation and increased levels of circulating pro-inflammatory mediators which may play an important role in the pathogenesis of insulin resistance. The binding of these mediators to their membrane-bound receptors activates intracellular signaling pathways that facilitate the dissociation of nuclear factor NF- $\kappa B$ from its inhibitor proteins. $\mathrm{NF}-\kappa \mathrm{B}$ subsequently enhances the transcription of a vast array of genes encoding various inflammatory mediators. [46]

NF- $\kappa \mathrm{B}$ pathways can be upregulated by other stimuli such as elevated FFAs, AGEs, ROS and endoplasmatic reticulum stress, which are frequently present in diabetic patients [47].

In an attempt to clarify the role played by the RAAS in the development of diabetes and diabetic nephropathy, the present study examined the effect of ACEI in modulating the course of DN in type II diabetic rats.

Diabetic nephropathy rats treated with lisinopril for one month (group 4) showed a significant 
decrease in SBP and DBP compared to both type II diabetic rats group and diabetic nephropathy rats group. Moreover, no significant change was observed compared to the control group.

Angiotensin converting enzyme inhibitors therapy not only inhibits ANG II production but also increases the output of the vasodilatory factors as bradykinin, NO, cGMP, prostaglandin E2, and prostacyclin [48].

Angiotensin converting enzyme inhibitors are also important in significantly improving arterial compliance through cytoprotection of vascular endothelium [49].

Diz et al., [50] proposed that the RAAS facilitates the sympathetic nervous system and that ACE inhibition and angiotensin receptor blockade are anti-adrenergic.

Lisinopril-treated diabetic nephropathy rats showed a significant decrease in fasting blood glucose compared to both type II diabetic rats group and diabetic nephropathy rats group. While they showed a significant reduction in fasting blood insulin compared to the diabetic nephropathy group but not to type II diabetic group (Fig. 4).

A Number of studies have also indicated that drugs which interfere with the renin-angiotensin system may also decrease levels of advanced glycation end products (AGEs) [51].

Regarding blood urea, lisinopril-treated diabetic nephropathy rats showed a significant decrease compared to diabetic nephropathy rats, but the drop was insignificant compared to type II diabetic rats group (Fig. 1). Treatment with lisinopril for one month significantly decreased UAE and increased albumin/creatinine ratio compared to both type II diabetic rats and diabetic nephropathy rats (Figs. 2,3).

Anyway, the values of these parameters in diabetic nephropathy rats did not return to that in the control group.

The anti-proteinuric and kidney-protecting effects of the ACEIs originally were thought to be attributable purely to hemodynamic effects, relieving the glomerulus by opening the efferent arterioles (post-glomerular), thereby reducing glomerular capillary pressure [52].

The pleiotropic effects of ACEI include antiinflammatory and antioxidant [53], and also antithrombotic, and profibrinolytic activities [54].
There are many other reports on the effects of ACEIs on renal function and proteinuria, most of which, but not all, have shown benefit and broadly support one or more of the above hypotheses. Despite solid clinical data, the mechanisms underlying this protective effect of RAAS blockade appear to be complex and has yet to be solved [55]

Lisinopril-treated diabetic nephropathy rats also showed a significant decrease in NF- $\mathrm{KB}$ gene expression compared to both type II diabetic rats and diabetic nephropathy rats. However, values remained higher than that in the control group (Fig. $6)$.

Thiamine and its derivatives have been discovered to decrease the activation of some of the biochemical pathways which are activated by the hyperglycemic process [56].

Thiamine deficiency appears to impair the normal endocrine function of the pancreas and exacerbate hyperglycemia. Early studies showed that insulin synthesis and secretion were altered in the pancreatic endocrine cells of thiaminedeficient rats [56].

This work also aims to study and evaluate the impact of thiamine in the course of DM and in the treatment of diabetic nephropathy in type II diabetic rats. And compare its effects against the effects of lisinopril.

Diabetic nephropathy rats treated with thiamine mononitrate for one month (group 5) showed no change in SBP compared to the diabetic group rats. However, SBP decreased significantly in relation to diabetic nephropathy rats, and at the same time was significantly high compared to the diabetic nephropathy rats treated with lisinopril for one month. DBP did not change significantly compared to both the diabetic and diabetic nephropathy rats. While it was significantly high compared to rats treated with lisinopril for one month. Both SBP and DBP did not reach their control values (Figs. $7,8)$.

A recent study demonstrated that thiamine decreases the oxidative stress and the production of the reactive oxygen species (ROS), and also upregulates the production of the endothelial nitric oxide synthase enzyme to enhance the generation and bioavailability of nitric oxide (NO) and subsequently improves the integrity of vascular endothelium and prevent experimental vascular endothelial dysfunction [57]. 
Balakumar et al., [58] concluded that diabetesinduced oxidative stress, lipids alteration, and subsequent development of vascular endothelial dysfunction may be responsible for the induction of nephropathy in diabetic rats.

Thiamine administration as a therapeutic agent in cases of diabetes mellitus, can reduce the formation of harmful by-products of glucose metabolism, and can reduce the expected oxidative stress and improve endothelial function. The potential benefit of long-term replacement in those with diabetes is not yet known but may reduce cardiovascular risk and angiopathic complications [60].

In diabetic nephropathy rats treated with thiamine mononitrate, fasting blood glucose was significantly low compared to diabetic nephropathy rats, and was significantly high compared to lisinopril-treated rats for one month. Fasting blood glucose levels did not show a significant change compared to type II diabetic rats (Fig. 4). Treatment with thiamine mononitrate showed insignificant decrease in fasting blood insulin compared to DN rats. However, fasting blood insulin was significantly high compared to both type II diabetic rats and lisinopril-treated rats. Both blood glucose and insulin did not return to their control values in thiamine-treated rats (Fig. 5).

Our results regarding fasting blood glucose and fasting blood insulin are compatible with those that announce that thiamine may modulate diabetic complications by controlling glycemic status in diabetic patients [59].

Additionally, deficiency of thiamine was observed to be associated with dysfunction of (3-cells and impaired glucose tolerance [61].

Thiamine deficiency leads to a marked impairment in insulin synthesis and secretion [62]. Besides, published data suggest that thiamine metabolism in diabetes is deficient [63]. Thereby insulin deficiency may exacerbate thiamine deficiency and vice versa. Many observational studies and clinical trials have recently linked several vitamin deficiencies with the pathological process of diabetes; including thiamine [64]

Administration of thiamine or a derivative can influence carbohydrate metabolism by reducing metabolism through the alternate pathways of metabolism and improving metabolism via the pentose phosphate pathway. This has been demonstrated in diabetic animal models where treatment with thiamine reduced fasting glucose and $\mathrm{HbA} 1 \mathrm{c}$ levels [65].
As regard blood urea, diabetic nephropathy rats treated with thiamine for one month showed a significant decrease compared to diabetic nephropathy rats group. Blood urea did not significantly change compared to both type II diabetic rats group and lisinopril-treated rats (Fig. 1). Urinary albumin excretion in thiamine mononitrate-treated rats was significantly low compared to diabetic nephropathy rats, but it did not return to the control value. While it was significantly high compared to both type II diabetic rats and lisinopril-treated rats (Fig. 2). Blood albumin/creatinine ratio in thiamine mononitrate-treated rats was significantly elevated compared to diabetic nephropathy rats, but it did not return to the control value. While it was significantly low compared to both type II diabetic rats and lisinopril-treated rats (Fig. 3).

Tk (Transketolase) variants and reduced activities of Tk enzyme were found in diabetic patients [66]. Genetic variability in Tk and Tk-like might contribute to the progression of diabetic nephropathy and mortality [67]. Thiamine regulates the expression genes that code for enzymes using thiamine as cofactor.

High dose of thiamine and benfotiamine (a synthetic derivative of thiamine) increased $\mathrm{Tk}$ expression in renal glomeruli and associated with decreased activation of PKC and also decreased protein glycation and oxidative stress [39].

Another study showed that the vitamin prevented oxidative stress induced by the mutagen 4nitroquinoline-1-oxide, the uremic toxin indoxyl sulfate, and the peptide hormone angiotensin II in three different kidney cell lines [68].

Diabetic nephropathy rats treated with thiamine mononitrate for one month showed an insignificant change in NF- $\mathrm{KB}$ gene expression compared to both type II diabetic rats and diabetic nephropathy rats, and it did not return to its control value. While they showed a significantly high NF- $\mathrm{KB}$ gene expression compared to diabetic nephropathy rats treated with lisinopril (Fig. 7).

Results of the present work were positively correlated with the studies that state that dysfunction of beta-cells and impaired glucose tolerance occurs in thiamine deficiency, and that thiamine deficiency leads to a marked impairment in insulin synthesis and secretion, and this indicates that thiamine therapy may have a future role in modulating the course of DM and its vascular complications. Our results also emphasized the renoprotective role of ACEI in type II diabetes where it 
significantly reduced UAE and had an efficient impact in slowing the progression of diabetic nephropathy.

Combining the use of thiamine with ACEI as a potential effective treatment in diabetic patients should be taken in consideration, and can make us avoid the possible side effects and disadvantages of the prolonged use of ACEI where there are studies that showed that treatment with ACEIs may be associated with so-called "angiotensin escape" characterized by the return of plasma ANG II concentration to pretreatment levels (although the beneficial effects on blood pressure usually persist).

Moreover, Schoolwerth and colleagues [52] stated that, although ACE inhibitor therapy usually improves renal blood flow and sodium excretion rates in congestive heart failure and reduces the rate of progressive renal injury in chronic renal disease, its use can also be associated with a syndrome of "functional renal insufficiency" and/or hyperkalemia. This form of acute renal failure, as assessed by serum creatinine values, most commonly develops shortly after initiation of ACEI therapy but can be observed after months or years of therapy, even in the absence of prior ill effects. Such side effects can be ameliorated by keeping the lowest possible dose which can be helped by other adjunctive therapies as thiamine. Which can potentially have a marked importance as an adjunctive therapeutic agent.

\section{Conclusion:}

From the previously obtained results data in this study showed that there was a significant improvement in both groups exposed to thiamine and ACE inhibitors.

The use of thiamine in type $2 \mathrm{DM}$ significantly improved the renal functions, lowered the blood glucose level, increased insulin sensitivity and lowered the arterial blood pressure may be through its action in preventing the activation of the biochemical pathways induced by hyperglycemia in DM. However, its protective effects were less than those offered by the ACE inhibitors. Which is the known gold standard used in diabetic nephropathy. So thiamine may be used as an adjunctive treatment in type 2 diabetes mellitus. To minimize the side effects caused by the ACE inhibitors. However, its effects if used solely as a therapeutic agent to delay the complications is still in doubt and needs further investigations.

\section{Conflict of interest:}

The authors of this study declare that they have no conflict of interests regarding this study.

\section{Funding:}

This study was self-funded. All author contributed equally in the funding and no external funding resources or research grants were used in this study.

\section{Acknowledgement:}

I want to thank all the authors for their valuable effort in this manuscript.

I would like to express my gratitude to the department of human physiology, faculty of medicine, Cairo university for providing administrative and technical support for this work.

\section{References}

1- LONGO L., KASPER L., JAMESON J.L., FAUCI A.S., HAUSER S.L. and LOSCALZO J.: Harrison's Principles of Internal Medicine, 18 th ed., New York: McGraw-Hill, 2982, 2012.

2- LIM A.K.H.: Diabetic nephropathy-complications and treatment. Int. J. NephrolRenovasc. Dis., 7: 361-381, 2014.

3- REMUZZI G., MACIA M. and RUGGENENTI P.: Prevention and Treatment of Diabetic Renal Disease in Type 2 Diabetes: The BENEDICT Study, 17 (4 Suppl 2): S9097, 2006.

4- COLLINS A.J., KASISKE B., HERZOG C., CHEN S.C., EVERSON S., CONSTANTINI E., et al.: Excerpts from the United States Renal Data System Annual Data Report: Atlas of end-stage renal disease in the United States. Am. J. Kidney. Dis., 42 (6 Suppl 5): A5-7, S1-230, 2003.

5- SINGH V.P., BALI A., SINGH N. and JAGGIAS: Advanced glycation end products and diabetic complications. Korean. J. Physiol. Pharmacol. Feb., 18 (1): 1-14, 2014.

6- HA H. and LEE H.B.: Reactive oxygen species as glucose signaling molecules in mesangial cells cultured under high glucose. Kidney. Int. Suppl., 77: S19-25, 2000.

7- STADLER K.: Oxidative stress in diabetes. Adv. Exp. Med. Biol., 771: 272-287, 2012.

8- MIYATA T., VAN YPERSELE DE STRIHOU C., UEDA Y., ICHIMORI K., INAGI R., ONOGI H., ISHIKAWA N., NANGAKU M. and KUROKAWA K.: Angiotensin II receptor antagonists and angiotensin-converting enzyme inhibitors lower in vitro the formation of advanced glycation end products: Biochemical mechanisms. J. Am Soc. Nephrol., 13 (10): 2478 -2487, 2002.

9- KANWAR Y.S., WADA J., SUN L., XIE P., WALLNER E.I., CHEN S., CHUGH S. and DANESH F.R.: Diabetic nephropathy: Mechanisms of renal disease progression. Exp. Biol. Med. (Maywood), 233 (1): 4-11, 2008.

10- SINGH R., SINGH A.K., ALAVI N. and LEEHEY D.J.: Mechanism of increased angiotensin II levels in glomerular mesangial cells cultured in high glucose. J. Am. Soc. Nephrol., 14 (4): 873-880.

11-ZIYADEH F.N. and WOLF G.: Pathogenesis of the podocytopathy and proteinuria in diabetic glomerulopathy. Curr. Diabetes. Rev., 4 (1): 39-45, 2003, 2008. 
12- TOJO A., ASABA K. and ONOZATO M.L.: Suppressing renal NADPH oxidase to treat diabetic nephropathy. Expert Opin. Ther. Targets, 11 (8): 1011-1018, 2007.

13- LEE H.S.: Mechanisms and consequences of TGF- $\beta$ overexpression bypodocytes in progressive podocyte disease. Cell. Tissue. Res., 347 (1): 129-140, 2012.

14- BELTRAMO E., BERRONE E., TARALLO S. and PORTA M.: Effects of thiamine and benfotiamine on intracellular glucose metabolism and relevance in the prevention of diabetic complications. Acta. Diabetol., 45 (3): 13 1$141,2008$.

15- CNOP M., WELSH N., JONAS J.C., JÖRNS A., LENZEN S. and EIZIRIK D.L.: Mechanisms of pancreatic betacell death in type 1 and type 2 diabetes: Many differences, few similarities. Diabetes, 54 (Suppl 2): S97-107, 2005.

16- KARIN M. and GRETEN F.R.: NF-kappaB: Linking inflammation and immunity to cancer development and progression. Nat. Rev. Immunol., 5 (10): 749-759, 2005.

17- NAVARRO-GONZÁLEZ J.F., MORA-FERNÁNDEZ C., MUROS DE FUENTES M. and GARCÍA-PÉREZ J.: Inflammatory molecules and pathways in the pathogenesis of diabetic nephropathy. Nat. Rev. Nephrol., 7 (6): $327-$ 340, 2011.

18- RUIZ-ORTEGA M., RUPÉREZ M., ESTEBAN V., RODRÍGUEZ-VITA J., SÁNCHEZ-LÓPEZ E, CARVAJAL G. and EGIDO J.: Angiotensin II: A key factor in the inflammatory and fibrotic response in kidney diseases. Nephrol. Dial. Transplant., 21 (1): 16-20, 2006.

19- MEZZANO S., AROS C., DROGUETT A., BURGOS M.E., ARDILES L., FLORES C., SCHNEIDER H., RUIZORTEGA M. and EGIDO J.: NF-kappaB activation and overexpression of regulated genes in human diabetic nephropathy. Nephrol. Dial. Transplant., 19 (10): 25052512, 2004.

20- IWAMOTO M., MIZUIRI S., ARITA M. and HEMMI H.: Nuclear factor- $\kappa$ Bactivation in streptozotocin-induced diabetic rat kidneys: Evidence for involvement of Pselectin in diabetic nephropathy.Tohoku. J. Exp. Med, 206 (2): 163-171, 2005.

21- YAMAGISHI S. and MATSUI T.: Advanced glycation end products, oxidative stress, and diabetic nephropathy. Oxid. Med. Cell. Longev., 3 (2): 101-108, 2010.

22- YI B., HU X., ZHANG H., HUANG J., LIU J., HU J., LI W. and HUANG L.: Nuclear NF- $\kappa B$ p65 in peripheral blood mononuclear cells correlates with urinary MCP-1, RANTES and the severity of type 2 diabetic nephropathy. PLoS. One., 9 (6): e99633, 2014.

23- MKRTCHYAN G., ALESHIN V., PARKHOMENKO Y., KAEHNE T., LUIGI DI SALVO M., PARRONI A., CONTESTABILE R., VOVK A., BETTENDORFF L. and Bunik V.: Molecular mechanisms of the non-coenzyme action of thiamine in brain: Biochemical, structural and pathway analysis. Sci. Rep., 5: 12583, 2015.

24- RODWELL V.W., BENDER DAVID A., BOTHAM K.M., KENNELLY P.J. and WEIL P.A.: Harper's Illustrated Biochemistry. $30^{\text {th }}$ ed., New York: McGraw Hill, 550: 555-556, 2015.

25- CLARK J.A., BURNY I., SARNAIK A.P. and AUDHYA TK.: Acute thiamine deficiency in diabetic ketoacidosis:
Diagnosis and management. Pediatr. Crit. Care. Med., 7 (6): 595-599, 2006.

26- HAMMES H.P., DU X., EDELSTEIN D., TAGUCHI T., MATSUMURA T., JU Q., LIN J. BIERHAUS A., NAWROTH P., HANNAK D., NEUMAIER M., BERGFELD R., GIARDINO I. and BROWNLEE M.: Benfotiamine blocks three major pathways of hyperglycemic damage and prevents experimental diabetic retinopathy. Nat. Med., 9 (3): 294-299, 2003.

27- THORNALLEY P.J., BABAEI-JADIDI R., AL ALI H., RABBANI N., ANTONYSUNIL A., LARKIN J., AHMED A., RAYMAN G. and Bodmer C.W.: High prevalence of low plasma thiamine concentration in diabetes linked to a marker of vascular disease. Diabetologia, 50 (10): 21642170, 2007.

28- RODRIGUEZ MELENDEZ R.: Importance of watersoluble vitamins as regulatory factors of genetic expression. Rev. Invest. Clin., 54 (1): 77-83, 2002.

29- SCHUMMER C.M., WERNER U., TENNAGELS N., SCHMOLL D., HASCHKE G., JURETSCHKE H.P., PATEL M.S., GERL M., KRAMER W. and HERLING A.W.: Dysregulated pyruvate dehydrogenase complex in Zucker diabetic fatty rats. Am. J. Physiol. Endocrinol. Metab., 294 (1): E88-96, 2008.

30- WIENEN W., RICHARD S., CHAMPEROUX P. and AUDEVAL-GERARD C.: Comparative antihypertensive and renoprotective effects of telmisartan and lisinopril after long-term treatment in hypertensive diabetic rats. J. Renin. Angiotensin Aldosterone Syst., 2 (1): 31-36, 2001.

31- BABAEI-JADIDI R., KARACHALIAS N., AHMED N., BATTAH S. and THORNALLEY P.J. : Prevention of incipient diabetic nephropathy by high-dose thiamine and benfotiamine. Diabetes, 52 (8): 2110-2120, 2003.

32- XIANG X., WANG Z., ZHU Y., BIAN L. and YANG Y.: Dosage of streptozocin in inducing rat model of type 2 diabetes mellitus. Wei. Sheng. Yan. Jiu., 39 (2): 138-142, 2010.

33- KRAEGEN E.W., JAMES D.E., STORLIEN L.H., BURLEIGH K.M. and CHISHOLM D.J.: In vivo insulin resistance in individual peripheral tissues of the high fat fed rat: Assessment by euglycaemic clamp plus deoxyglucose administration. Diabetologia. Mar., 29 (3): 192198, 1986.

34- RAMESH B., SARAVANAN R. and PUGALENDI K.V.: Effect of Dietary Substitution of Groundnut Oil on Blood Glucose, Lipid Profile, and Redox Status in Streptozotocindiabetic Rats. Yale. J. Biol. Med.,79 (1): 9-17, 2006.

35- KIRAN G., NANDINI C.D., RAMESH H.P. and SALIMATH P.V.: Progression of early phase diabetic nephropathy in streptozotocin-induced diabetic rats: Evaluation of various kidney-related parameters. Indian J. Exp. Biol., 50 (2):133-140, 2012.

36- DE LA RICA and STEVENS M.M.: Plasmonic ELISA for the ultrasensitive detection of disease biomarkers with the naked eye. Nature Nanotechnology, 7 (12): 821-824, 2012.

37- MALKOFF J.: Non-Invasive Blood Pressure for Mice and Rats. Animal Lab News, 1, 2011.

38- NINFA A.J., BALLOU D.P. and BENORE M.: Fundamental Laboratory Approaches for Biochemistry and 
Biotechnology. ${ }^{2 n d}$ ed., Chichester, United Kingdom: John Wiley and Sons Ltd, 408-410, 2009.

39- ZHOU M.S., WANG A. and YU H.: Link between insulin resistance and hypertension: What is the evidence from evolutionary biology? Diabetol. Metab. Syndr., 6 (1): 12, 2014.

40- JIA G., AROOR A.R., DEMARCO V.G., MARTINEZLEMUS L.A., MEININGER G.A. and SOWERS J.R.: Vascular stiffness in insulin resistance and obesity. Front. Physiol., 6: 231, 2015.

41- VAN BUREN P.N. and TOTO R.: Hypertension in diabetic nephropathy: epidemiology, mechanisms, and management. Adv. Chronic. Kidney. Dis., 18 (1): 28-41, 2011.

42- ECHEVERRÍA-RODRÍGUEZ O., DEL VALLE-MON DRAGÓN L. and HONG E.: Angiotensin 1-7 insulin sensitivity by increasing skeletal muscle glucose uptake in vivo. Peptides, 51: 26-30, 2014.

43- DABLA P.K.: Renal function in diabetic nephropathy. World. J. Diabetes., 1 (2): 48-56, 2010.

44- SATCHELL S.C. and TOOKE J.E.: What is the mechanism of microalbuminuria in diabetes: A role for the glomerular endothelium? Diabetologia, 51 (5): 714-725, 2008.

45- KOROSHI A.: Microalbuminuria, is it so important? Hippokratia, 11 (3): 105-107, 2007.

46- ANDREASEN A.S., KELLY M., BERG R.M., MØLLER K. and PEDERSEN B.K.: Type 2 diabetes is associated with altered NF-KB DNA binding activity, JNK phosphorylation, and AMPK phosphorylation in skeletal muscle after LPS. PLoS. One., 6 (9): e23999, 2011.

47- GOH S.Y. and COOPER M.E.: Clinical review: The role of advanced glycation end products in progression and complications of diabetes. J. Clin. Endocrinol. Metab., 93 (4): 1143-1152.

48- ERDÖS E.G. and MARCIC B.M.: Kinins, receptors, kininases, and inhibitors-where did they lead us? BiolChem, 382 (1): 43-47, 2001.

49- NEUTEL J.M.: Effect of the renin-angiotensin system on the vessel wall: Using ACE inhibition to improve endothelial function. J. Hum. Hypertens., 18 (9): 599-606, 2004.

50- DIZ D.I., ARNOLD A.C., NAUTIYAL M., ISA K., SHALTOUT H.A. and TALLANT E.A.: Angiotensin peptides and central autonomic regulation. Curr. Opin. Pharmacol., 11 (2): 131-137, 2011.

51- NANGAKU M., MIYATA T., SADA T., MIZUNO M., INAGI R., UEDA Y., et al.: Anti-hypertensive agents inhibit in vivo the formation of advanced glycation end products and improve renal damage in a type 2 diabetic nephropathy rat model. J. Am. Soc. Nephrol., 14 (5): 1212-1222, 2003.

52- SCHOOLWERTH A.C., SICA D.A., BALLERMANN B.J. and WILCOX C.S.: Council on the Kidney in Cardiovascular Disease and the Council for High Blood Pressure Research of the American Heart Association: Renal considerations in angiotensin converting enzyme inhibitor therapy: A statement for healthcare professionals from the Council on the Kidney in Cardiovascular Disease and the Council for High Blood Pressure Research of the American Heart Association. Circulation, 104 (16): 19851991,2001
53- SIRONI L., NOBILI E., GIANELLA A., GELOSA P. and TREMOLI E.: Anti-inflammatory properties of drugs acting on the renin-angiotensin system. Drugs Today (Barc), 41 (9): 609-622, 2005.

54- KOTHARI S.A., LE M.K. and GANDHI P.J.: Effects of angiotensin-converting enzyme inhibitors on thrombotic mediators: Potential clinical implications. J. Thromb. Thrombolysis, 15 (3): 217-225, 2003.

55- JALAL S., SOFI F.A., ABASS S.M., ALAI M.S., BHAT M.A., RATHER H.A., LONE N.A. and SIDDIQI M.A.: Effect of amlodipine and lisinopril on microalbuminuria in patients with essential hypertension: A prospective study. Indian. J. Nephrol., 20 (1): 15-20, 2010.

56- LUONG K.V. and NGUYEN L.T.: The impact of thiamine treatment in the diabetes mellitus. J. Clin. Med. Res., 4 (3): 153-160, 2012.

57- VERMA S., REDDY K. and BALAKUMAR P.: The defensive effect of benfotiamine in sodium arseniteinduced experimental vascular endothelial dysfunction. Biol. Trace. Elem. Res., 137 (1): 96-109, 2010

58- BALAKUMAR P., CHAKKARWAR V.A. and SINGH M.: Ameliorative effect of combination of benfotiamine and fenofibrate in diabetes-induced vascular endothelial dysfunction and nephropathy in the rat. Mol. Cell. Biochem., 320 (1-2): 149-162.

59- ARORA S., LIDOR A., ABULARRAGE C.J., WEISWASSER J.M., NYLEN E., KELLICUT D. and SIDAWY A.N.: Thiamine (vitamin B-1) improves endothelium-dependent vasodilatation in the presence of hyperglycemia. Annals of Vascular Surgery, 20 (5): 653658,2006

60- PAGE G.L., LAIGHT D. and CUMMINGS M.H.: Thiamine deficiency in diabetes mellitus and the impact of thiamine replacement on glucose metabolism and vascular disease. Int. J. Clin. Pract., 65 (6): 684-690, 2011.

61- THORNALLEY P.J.: The potential role of thiamine (vitamin B1) in diabetic complications. Curr. Diabetes. Rev., 1 (3): 287-298, 2005.

62- DEBSKI B., KURYL T., GRALAK M.A., PIERZYNOWSKA J. and DRYWIEN M.: Effect of inulin and oligofructose enrichment of the diet on rats suffering thiamine deficiency. J. Anim. Physiol. Anim. Nutr., (Berl), 95 (3) 335-342, 2011.

63- PÁCAL L., KURICOVÁ K. and KAN KOVÁ K.: Evidence for altered thiaminemetabolism in diabetes: Is there a potential to oppose gluco- and lipotoxicity by rational supplementation? World J. Diabetes, 5 (3): 288-295, 2014.

64- KARACHALIAS N., BABAEI-JADIDI R., RABBANI N. and THORNALLEY P.J.: Increased protein damage in renal glomeruli, retina, nerve, plasma, and urine and its prevention by thiamine and benfotiamine therapy in a rat model of diabetes. Diabetologia, 53 (7): 1506-1516, 2010.

65- THORNALLEY P.J., BABAEI-JADIDI R., KARACHALIAS N. and RABBANI N.: Prevention of decline in glycemic control in streptozocin-induced diabetic rats by thiamine but not by Benfotiamine. Diabet. Med., 27 (Suppl 1): $74,2010$. 
66- ZHAO J. and ZHONG C.J.: A review of research progress of transketolase. Neurosci. Bull., 25 (2): 94-99, 2009.

67- PACAL L., TOMANDL J., SVOJANOVSKY J., KRUSOVA D., STEPANKOVA S., REHOROVA J., OLSOVSKY J., BELOBRÁDKOVÁ J., TANHÄUSEROVÁ V., TOMANDLOVÁ M., MUZÍK J. and KANKOVÁ K.: Role of thiamine status and genetic variability in transke- tolase and other pentose phosphate cycle enzymes in the progression of diabetic nephropathy. Nephrol Dial Transplant, 26 (4): 1229-1236, 2011.

68- SCHMID U., STOPPER H., HEIDLAND A. and SCHUPP N.: Benfotiamine exhibits direct antioxidative capacity and prevents induction of DNA damage in vitro. Diabetes Metab. Res. Rev., 24 (5): 371-377, 2008.

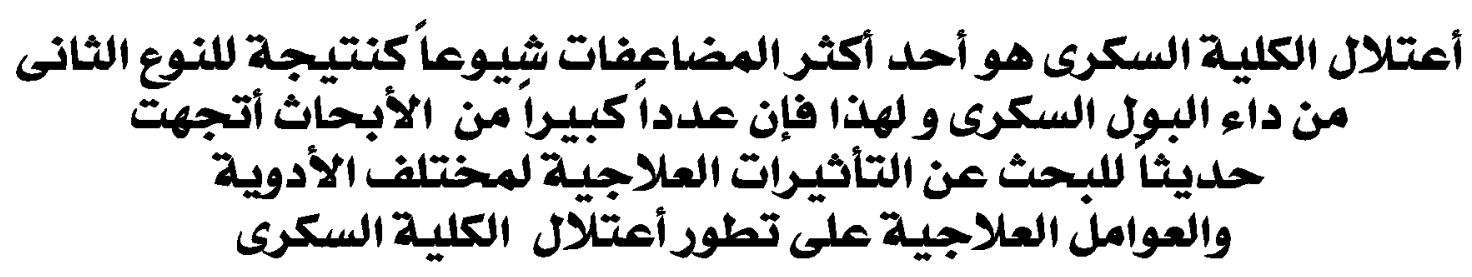

الهدف من البحث: المقارنة بين التأثيرات الوقائية للثيامين بالإضافة إلى مثبطات الإنزيم المحل للأنجيوتنسين فى الكلى المصابة بالنوع الثانى من مرض البول من البحف: السكرى.

$$
\text { طرق البحث: تم تقسيم ها مجموعه +م من ذكود الفئران البيضاء إلى خمس هجموعات. }
$$

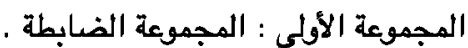

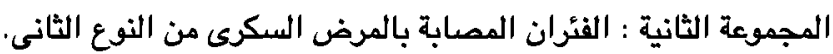

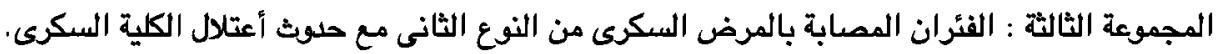

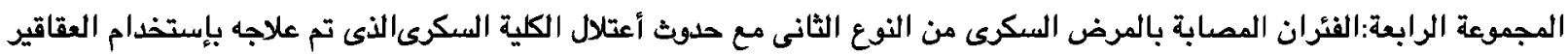

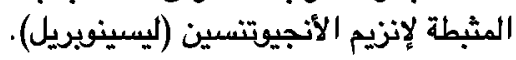

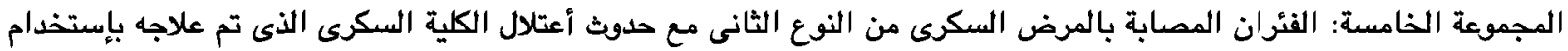

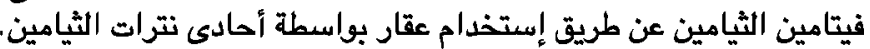

تم تجميع عينات الدم لقياس مستوى السكر فى الدم، ومستقى هرمون الأنسولين فى الدم، ومستوى اليوريا والرياتينين فى الدم كمؤثرات

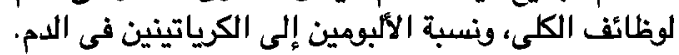

$$
\text { كما تم جمع عينات البول لقياس إفراز الألبومين البولى. }
$$

كما تم قياس ضغط الدم الأنقباضى وضغط الدم الأنبساطى. وتم تقدير الجينى لعامل الكابا ب كمعامل للألتهاب.



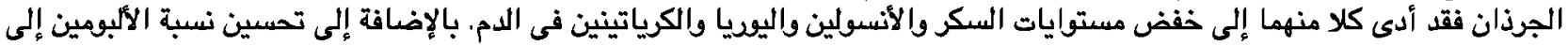

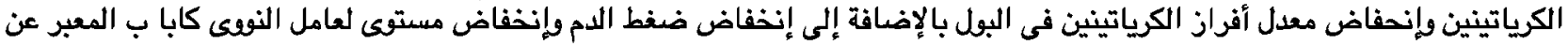
حالة الالتهاب.

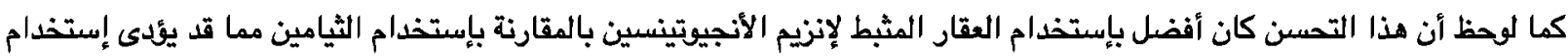



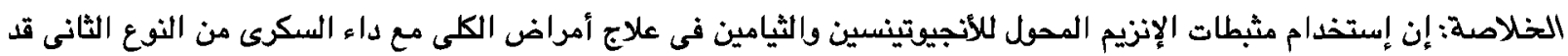

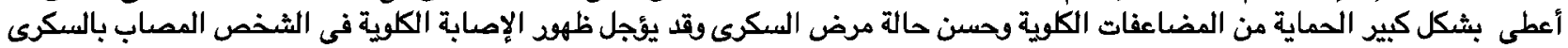

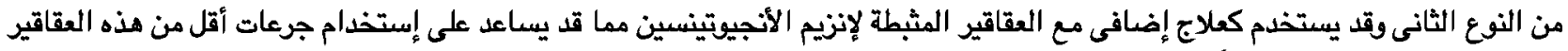

